Murawska, D. (2019). Rola interesariuszy w innowacjach społecznych. W: N. Laurisz, A. Pacut (red.). Ekonomia Społeczna. Innowacyjność społeczna w Polsce (s. 11-22). Kraków: Uniwersytet Ekonomiczny w Krakowie. https:// doi.org/10.15678/ES.2019.2.02

\title{
Rola interesariuszy w innowacjach społecznych
}

\section{Daria Murawska}

\begin{abstract}
Streszczenie: We współczesnym świecie rośnie znaczenie innowacji społecznych w kontekście poszukiwania rozwiązań stanowiących odpowiedź na bieżące wyzwania społeczne czy dotyczące zrównoważonego rozwoju. Nie jest możliwe ich skuteczne projektowanie oraz wdrażanie bez zaangażowania interesariuszy. Stąd, celem niniejszego opracowania jest analiza możliwych rozwiązań z zakresu wyłaniania oraz angażowania interesariuszy w innowacje społeczne. Praca bazuje na przeglądzie literatury polskiej i zagranicznej oraz wykorzystuje dostępne narzędzia mapowania i angażowania interesariuszy. W wyniku rozważań wykazano, że współpraca z interesariuszami jest istotnym elementem rozwijania innowacji społecznych, pozwalającym lepiej zrozumieć istotę wyzwań, potrzeby beneficjentów oraz wpływającym na łatwiejszy dostęp do ważnych zasobów.
\end{abstract}

Słowa kluczowe: innowacje społeczne; powstawanie innowacji; interesariusze; angażowanie

Kody JEL: $\quad$ O3; L3; Z13

\section{Wprowadzenie}

Innowacje, w tym innowacje społeczne, w potocznym rozumieniu kojarzą się przede wszystkim z tym co przełomowe, tworzące nową jakość, wprowadzające "rewolucyjne" rozwiązania do naszego życia. „Dziś nie wystarczy chcieć naprawiać świat - ważne jest, by umieć to robić sprawnie, szybko i sprytnie. Wykorzystując najlepsze możliwe środki, znajdując połączenia, których nikt wcześniej nie znalazł, zastanawiając się, jak ten sam problem można rozwiązać lepiej niż zrobili to poprzednicy, a istniejące - choć skuteczne - rozwiązania zastępować jeszcze skuteczniejszymi. To właśnie, w dużym uproszczeniu, kryje się za pojęciem innowacji społecznych - chodzi po prostu o poszukiwanie jeszcze lepszych, nowatorskich sposobów na naprawę choćby małego wycinka rzeczywistości" (Mencwel i Wygnański, 2014, s. 5). Chęć poprawy świata czy jakości ludzkiego życia to cele bardzo odważne, które w swojej istocie wymagają kooperacji oraz "potrzeba współpracy na rzecz nowego podejścia do kreowania zmian. Samodzielnie ani państwo, ani biznes, ani organizacje związane z trzecim sektorem nie są w stanie go urzeczywistnić/osiągnąć go na poziomie, który prowadzi do realnej zmiany" (Olejniczuk-Merta i Nowak, 2015, s. 13).

Innowacje społeczne dzieją się w konkretnym miejscu, w konkretnym czasie. To, co dla jednej grupy może być prostym rozwiązaniem, dla innej może stać się właśnie innowacją społeczną. Bez tego społecznego aspektu, jak otwarcie się na głos otoczenia czy środowiska, w którym innowacja ma być wdrażana, nie będzie ona miała wymiaru innowacji społecznej. To właśnie uczestnictwo osób zewnętrznych, potencjalnych beneficjentów, tych wszystkich 
jednostek i grup, na które innowacja społeczna będzie wpływać lub które mogą mieć wpływ na nią, czyli interesariuszy, jest kluczowym czynnikiem sukcesu projektowania oraz wdrażania innowacji społecznych.

Nie wszyscy interesariusze są znaczący dla danej innowacji społecznej, jedni mogą odgrywać kluczową rolę, być bardzo zaangażowani na każdym etapie, inni mogą mieć mniejsze znaczenie. Jednak w odniesieniu do innowacji społecznych są oni bardzo ważnym głosem, który, jeśli zostanie uwzględniony przez innowatora czy też organizację wdrażającą, może być realizowany sprawniej i skutecznie chociażby w wymiarze organizacyjnym, formalnym czy finansowym. Celem niniejszego opracowania jest przegląd oraz ocena możliwych rozwiązań z zakresu identyfikowania oraz angażowania interesariuszy w odniesieniu do innowacji społecznych. Ze względu na ograniczenia redakcyjne, nie pozwalające na pełną analizę tego zagadnienia, zostały zaprezentowane jedynie wybrane rozwiązania z tego zakresu.

\section{Przegląd literatury}

\subsection{Innowacje społeczne}

Pierwsze próby definiowania innowacji społecznych są przypisywane W.F. Ogburnowi (1969), który łączył je z działaniem dotyczącym wypełnienia luki kulturowej, rozumianej jako dystans pomiędzy rozwojem kulturowym i technicznym. Obecnie wskazuje się, że innowacje społeczne wykraczają poza ramy czasowe i nie mają granic, są przydatne i użyteczne, jeśli odpowiadają na potrzeby użytkownika, pomagając mu zaspokajać je od tych niematerialnych, po materialne (Wiktorska-Święcka i in., 2015, s. 23).

W literaturze przedmiotu rozróżnia się trzy główne nurty definiowania innowacji społecznych: przez pryzmat zarządzania, w kontekście współistnienia z innowacjami technologicznymi oraz jako pojęcie autonomiczne, wpisujące się w praktyki społeczne (tamże, s. 23).

W dokumentach Komisji Europejskiej pojęcie to definiowane jest jako rozwój i wdrażanie nowych pomysłów, zarówno produktów, usług, jak i modeli, których celem jest zaspokojenie potrzeb społecznych i tworzenie nowych relacji społecznych lub współpracy. Stają się one odpowiedzią na potrzeby społeczne, które mają wpływ na proces interakcji społecznych, a ich celem jest poprawa jakości ludzkiego życia. Innowacje społeczne są społeczne ze względu na swoje cele, jak również środki. Są nie tylko dobre dla społeczeństwa, ale również wzmacniają zdolność jednostek do działania (European Commission, 2013, s. 6).

Większość definicji opiera się na założeniu, że innowacje społeczne odnoszą się do nowych pomysłów (w zakresie produktów, usług i modeli) (Mulgan, 2012, s. 22), dodatkowo procesów, kanałów dystrybucji (Bisgaard, 2009 za: Wyrwa, 2014) czy nowych form zaangażowania obywatelskiego (Neumeier, 2012, s. 53). Są jednak głosy podkreślające, że innowacje społeczne „nie muszą być całkowicie oryginalne i wyjątkowe. Muszą jednak zawierać nowatorskie elementy w wymiarze relatywnym i rzeczywistym dotyczące zarówno branży, jak i sektora, terytorium instytucji czy użytkownika" (Lubimow-Burzyńska, 2014, s. 76).

Wielu badaczy wskazuje na lokalny wymiar innowacji społecznych w różnych aspektach, podkreślając, że innowacje społeczne mają służyć rozwiązywaniu problemów społecznych dotykających osób fizycznych oraz wspólnot (Goldenberg i in., 2004, s. 3), społeczności lokalnych (Moulaert i Nussbaumer, 2005, s. 2071) czy uwzględniając wszystkie te kategorie, od osób fizycznych, organizacji, otoczenie, społeczności po społeczeństwa (Cahill, 2010, s. 259). 
W niektórych definicjach kładzie się nacisk na globalny aspekt innowacji społecznych jako tych, które umożliwiają rozwiązywanie globalnych wyzwań, zarówno w odniesieniu do zagadnień środowiskowych, jak i społecznych (Bisgaard, 2009 za: Wyrwa, 2014).

Jeśli chodzi o definicje bardziej zoperacjonalizowane na potrzeby realizowanych programów, jak chociażby programu „Innowacje społeczne”, Narodowego Centrum Badań i Rozwoju wskazuje, że innowacje społeczne „oznaczają takie rozwiązania, które równocześnie odpowiadają na zapotrzebowanie społeczne, jak i powodują trwałą zmianę w danych grupach społecznych. Te rozwiązania mogą wiązać się z innowacyjnymi produktami, usługami bądź procesami, które umożliwiają odmienne rozwiązywanie typowych problemów społecznych. Przez innowacje społeczne (...) rozumie się zarówno społecznie uzasadnione innowacje techniczne i technologiczne, jak i innowacje stricte społeczne. Do kategorii innowacji technicznych i technologicznych możemy zaliczyć w szczególności takie rozwiązania, które są związane z dostosowaniami danego produktu do potrzeb szczególnego odbiorcy na przykład mieszkańców regionów Polski o słabo rozwiniętej infrastrukturze. Do kategorii innowacji stricte społecznych możemy zaliczyć takie rozwiązania, które dotyczą m.in. problemów ludzi w starszym wieku, niepełnosprawnych i bezrobotnych, a więc grup wymagających wsparcia ze strony państwa i społeczeństwa" (Narodowe Centrum Badań i Rozwoju, 2019).

W jednym z większych projektów w Europie wspierających innowacje społeczne - The Theoretical, Empirical and Policy Foundations for Building Social Innovation in Europe (TEPSIE) były one definiowane jako nowe rozwiązania, w tym produkty, usługi, modele, rynki, procesy, które równocześnie służą zaspokojeniu społecznej potrzeby (w sposób bardziej efektywny, niż inne rozwiązania) i prowadzą do nowych lub ulepszonych możliwości działania społeczeństwa, jak również przekładają się na efektywniejsze wykorzystanie posiadanych zasobów. Badacze w tym projekcie wskazali, że innowacje społeczne są „jedynym w swoim rodzaju podtypem innowacji, nowym rozwiązaniem, prowadzą do konkretnych rezultatów, którymi są mierzalne ulepszenia istniejących praktyk. Ponadto mogą pojawić się w każdym sektorze i często przecinają różne obszary i dziedziny" (Wiktorska-Święcka i in., 2015, s. 29).

\subsection{Koncepcja interesariuszy}

Pojęcie interesariuszy wiąże się z koncepcją społecznej odpowiedzialności biznesu, w której wskazuje się ich istotną rolę w funkcjonowaniu firmy. Twórcą teorii interesariuszy nazywany jest R. E. Freeman (1984). W odniesieniu do organizacji interesariuszem jest każda osoba lub grupa, która może wpływać na organizację lub taka, na którą wpływa organizacja, bądź podejmowane przez nią działania (Partridge i in., 2005, s. 6).

W odniesieniu do interesariuszy organizacji jednym z ważniejszych elementów budowania relacji jest dialog. Aby podjąć dialog z interesariuszami, każda organizacja musi właściwie się do tego procesu przygotować, począwszy od mapowania interesariuszy, poprzez dobór właściwych narzędzi, po budowanie relacji i angażowanie. Dla organizacji dostępna jest nawet seria standardów AA 1000 opracowana przez międzynarodową firmę konsultingową AccountAbility, podejmująca temat zarządzania relacjami z interesariuszami.

Innowacje społeczne, tak jak i organizacje pozarządowe lub firmy, które mogą je inicjować, mają swoich interesariuszy. Należy podkreślić, iż w przypadku innowacji społecznych interesariusze nie mogą być utożsamiani wyłącznie z beneficjentami tych rozwiązań. To pojęcie znacznie szersze, odnoszące się do wszystkich osób i grup, które mogą wpłynąć na innowację społeczną, jak również tych, na które innowacja społeczna może w jakikolwiek sposób oddziaływać. 
Bardzo istotnym elementem budowania relacji jest nawiązanie dialogu, rozumianego jako wzajemna wymiana informacji, a nie tylko ich jednostronne przekazywanie. W procesie dialogu budowana jest otwartość na różne środowiska, docenienie ich głosu i tego, jak mogą wpłynąć na dany proces. „Dialog potrafi połączyć również wokół jednego problemu i na tym głównie skupiają się organizacje, prowadząc dialog z interesariuszami. Dialog wykorzystuje w końcu kapitał interesariuszy do wprowadzenia zmiany społecznej. Kapitał interesariuszy określić można jako agregat zasobów wiedzy, relacji oraz gotowości dzielenia się swoim doświadczeniem, w końcu zaś zdolność do wspólnego działania i potencjał do wprowadzenia zmiany społecznej" (Andrejczuk i Abec, 2014, s. 8).

\section{Metoda badawcza}

Opracowanie ma na celu omówienie zagadnienia budowania relacji z interesariuszami w innowacjach społecznych. Aby zrealizować zamierzony cel dokonano przeglądu literatury, który w sposób syntetyczny przybliża różne podejścia teoretyczne do opisywanej tematyki. Tekst przygotowano w oparciu o literaturę przedmiotu z zakresu innowacji społecznych, a także bibliografii poruszającej zagadnienia związane z koncepcją interesariuszy. Istotne było wyjaśnienie, w jaki sposób interesariusze mogą wpływać na tworzenie innowacji społecznych i jaka jest ich rola w tym procesie. W opracowaniu uwzględnione zostały podejścia prezentujące możliwe rozwiązania z zakresu mapowania i kategoryzowania interesariuszy oraz ich angażowania w odniesieniu do innowacji społecznych. Do analizy teoretycznej na potrzeby opracowania wybrane zostały teksty autorów polskich i zagranicznych, aby prezentowana synteza uwzględniała istotne i nowo wydane publikacje dotyczące zarówno innowacji społecznych, jak również elementów teorii interesariuszy. Pozwoliło to na szczegółowe omówienie wskazanych zagadnień.

\section{Prezentacja wyników badania i ich omówienie}

\subsection{Tworzenie innowacji społecznych i rola interesariuszy w tym procesie}

„Proces innowacji ma na celu uaktywnienie społeczeństwa, co jest równie ważne jak cel i efekt wprowadzonej innowacji" (Lubimow-Burzyńska, 2014, s. 80). Dlatego tak istotne wydaje się angażowanie interesariuszy w tworzenie innowacji społecznych, gdyż jest to moment, w którym budowane są nowe relacje, wzmacniane jest zaufanie i wspierany rozwój kapitału społecznego. Tym bardziej, iż „proces innowacji społecznych często pociąga za sobą zmiany w stosunkach społecznych, a szczególnie w zakresie zarządzania i zwiększania udziału marginalizowanych lub niedostatecznie reprezentowanych grup społecznych" (tamże, s. 80).

Koniecznie jest więc poznanie procesu powstawania innowacji społecznych i dostrzeżenia udziału interesariuszy na poszczególnych jego etapach.

W modelowym ujęciu mówi się o sześciu kluczowych fazach w procesie tworzenia innowacji społecznych (Murray i in., 2010, s. 34) (por. rysunek 1). Pierwsza to identyfikowanie potrzeb (prompts) jednostek, grup czy społeczności, na które innowacja ma odpowiadać. W kolejnym kroku następuje proces generowania idei (proposals), w ramach którego rozwiane są pomysły, które są odpowiedzią na zidentyfikowane wcześniej potrzeby. Następnie innowacja społeczna jest weryfikowana, poprzez pilotażowe wdrożenie (prototypes). Jest to etap, na którym wprowadzane są niezbędne poprawki i wdrażane możliwe udoskonalenia. Po etapie pilotażowym następuje proces rozwoju czy też podtrzymania innowacji (sustaining), poprzez jej wdrożenie. 
Dzięki temu możliwe jest przejście do etapu skalowania (upowszechniania) innowacji, poprzez zwiększanie zasięgu jej oddziaływania czy wpływów (scaling). Ostatnim etapem jest ukonstytuowanie się zmiany systemowej (systematic change), do której prowadzi innowacja społeczna poprzez trwałą zmianę społeczną.

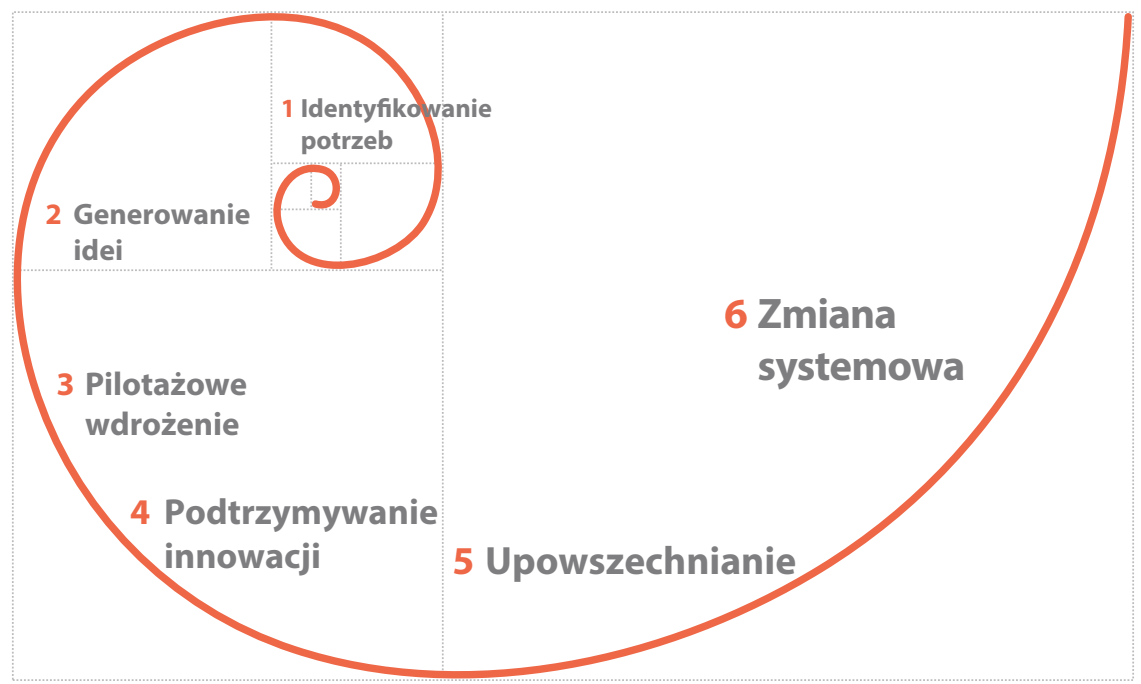

\section{Rysunek 1. Proces powstawania innowacji}

Źródło: (Murray i in., 2010, s. 11).

Jest to pewien model teoretyczny, który nie musi być elementem każdej wprowadzanej innowacji społecznej. Co więcej, w rzeczywistości poszczególne etapy mogą się na siebie nakładać lub być realizowane w innej kolejności. Wiele przedsięwzięć jest inicjowanych od praktycznych działań czy wprowadzenia prototypu. Zdarza się, że wdrażanie oraz praktyka rodzą nowe pomysły, które prowadzą do dalszych ulepszeń i innowacji. Podkreśla się istotę pętli informacji zwrotnej (feedback loops), które istnieją między każdym etapem, co sprawia, że proces jest iteracyjny, a nie liniowy, jak zostało to zaprezentowane na rysunku 1 (The Young Foundation, 2012, s. 34).

„Nie można mówić o innowacjach bez refleksji nad przestrzenią w jakiej powstają, przestrzenią dialogu. Innowacja tworzona zza biurka ma wielkie szanse na rozminięcie się z jej adresatem. Gdy powstaje w kontakcie z nim, w DIALOGU z nim, pojawia się możliwość nowych partnerstw, sojuszy, nowych idei, a w każdym razie większej adekwatności nowych rozwiązań" (Niziński, 2014, s, 4-5). Dialog i uzyskiwanie informacji zwrotnej nie będzie możliwe, o ile nie zaplanuje się właściwej komunikacji na każdym z etapów projektowania i wdrażania innowacji. Komunikacja musi być prowadzona w sposób zaplanowany, wybierając właściwe grupy interesariuszy i dostosowując do nich odpowiednie narzędzia.

Znaczenie prowadzenia dialogu oraz angażowania interesariuszy podkreśla się zwłaszcza w pierwszych fazach powstawania innowacji społecznych. Ich aktywne angażowanie ma wielką wagę, pomaga uzyskać dostęp do ważnych zasobów, które mogą nie być łatwo dostępne, jak środki finansowe, sieć relacji społecznych czy wiedza. Co więcej, to właśnie interesariusze mogą pomóc lepiej zrozumieć potencjalnych beneficjentów. „Współtworzenie 
(co-creation) odgrywa istotną rolę dla innowacji i innowacji społecznych, w szczególności jako zaangażowanie interesariuszy $w$ formułowanie i wdrażanie pomysłów na innowacje społeczne skutkuje większym zaangażowaniem i sukcesem. Współtworzenie nie jest nowym pomysłem, ale staje się coraz ważniejsze, ponieważ coraz więcej firm stosuje podejście oparte na zaangażowaniu wielu interesariuszy (multi-stakeholder approach) (Bhattacharya, 2013, s. 148).

\subsection{Identyfikowanie potrzeb (Prompts)}

Pomysły na innowacje społeczne mogą powstawać w wyniku zmian w otoczeniu, klęski czy nagłej potrzeby lub rozwijać się stopniowo. Na tym etapie innowatorzy społeczni mogą wykorzystywać różne techniki w celu odkrycia potrzeb społeczności. Istotne są również dane, w tym przykładowo analiza zestawów danych, wizualizacja i mapowanie, które mogą pomóc odkryć ukryte wzory potrzeb i wydobyć je na powierzchnię. Są również procesy identyfikacji potrzeb, które są bardzo zależne od użytkownika (user driven) i nastawione na informację zwrotną. W takim modelu to właśnie użytkownicy stają się odpowiedzialni za wszystkie etapy procesu badawczego, od projektu i rekrutacji, przez analizę danych, po pisanie i rozpowszechnianie (The Young Foundation, 2012, s. 35).

Na etapie identyfikowania potrzeb, bez otwarcia się na głos i udział interesariuszy, informację zwrotną od nich i uważnego słuchania, nie jest możliwe zaprojektowanie innowacji, która będzie w sposób właściwy odpowiadała na potrzeby beneficjentów.

\subsection{Generowanie idei (Proposals)}

$\mathrm{Na}$ etapie generowania idei wskazuje się na podejście odnoszące się do projektowania społecznego (social design). Jest to proces, który pozwala już na poziomie lokalnym wypracowywać rozwiązania na problemy ekonomiczne i społeczne. Przyczynia się do proponowania nowych wartości, które pomagają w działaniach administracji publicznej poprzez współpracę, eksperymenty i prototypowanie. Praktyki w ramach innowacji społecznych różnią się od tradycyjnych form planowania usług w sektorze publicznym, gdzie dominują formalne spotkania czy rozwiązania proponowane przez ekspertów. Praktyki innowacji społecznych są zwykle mniej formalne, angażują więcej osób, oferują więcej technik animacji, są bardziej interdyscyplinarne, znajdują nowe sposoby angażowania użytkowników i obywateli oraz zachęcają do wypracowywania rozwiązań nazywanych myśleniem out of the box. Wdrażają metody oparte na dowodach i często używają takich technik jak np. analiza porównawcza w celu zidentyfikowania dobrych praktyk w konkretnych dziedzinach (European Commission, 2013, s. 7).

W odniesieniu do innowacji bardzo podkreśla się nowatorstwo, nieszablonowe, twórcze myślenie out of the box. Twórczość jest procesem myślowym, który prowadzi do nowych oraz użytecznych rozwiązań. Najczęściej kreatywne myślenie było przypisywane jednostce, jednak badania wskazują, że tak rozumiana twórczość może być procesem, który jest celowo wywoływany w kontrolowany sposób, tak kształtując warunki, aby sprzyjały tworzeniu czy wymyślaniu innowacji (Chybicka, 2017, s. 12-13).

Bez względu na wybraną technikę czy narzędzia, które będą pomocne na tym etapie, ważnym elementem jest konieczność „....otwartości na dialog z różnymi grupami interesariuszy, który umożliwia dostosowanie rozwiązań do potrzeb ich adresatów oraz wdrażanie zmian systemowych, dających innowacjom społecznym trwały fundament" (Niziński, 2014, s. 4). 


\subsection{Pilotażowe wdrożenie (Prototypes)}

Możliwości testowania pomysłu w praktyce jest wiele, zazwyczaj są one wprowadzane, a następnie dostosowywane w zależności od pierwszych doświadczeń. Ważnymi elementami są eksperymenty, szybkie uczenie się (rapid learning), metody prób i błędów (trial and error), a nawet przypadek. Podkreśla się, że często te rozwiązania są pomijane, ponieważ rozwój jest postrzegany jako seria zaplanowanych kroków, które następują po sobie w racjonalny sposób. Jednak, jak to było przedstawione wcześniej, innowacje rzadko jest procesem liniowym. Co więcej, wymagają stałej interakcji pomiędzy popytem a podażą, potencjalnymi użytkownikami a ich dostawcami (The Young Foundation, 2012, s. 37). To właśnie proces nieustannych interakcji, konfrontowania, weryfikowania i testowania innowacji w warunkach społecznych, w odbiorze użytkowników, w ocenie interesariuszy jest kluczowym elementem wdrożenia jej z sukcesem.

Wskazuje się, że bardzo istotny jest „współudział przedstawicieli zarówno inicjatorów zmiany jak i beneficjentów danego projektu. Dzięki ich opinii w wyniku testów, rozwiązania niepraktyczne, nie akceptowane, negatywnie ocenione oraz nie zapewniające odpowiednich walorów użytkowych są odrzucane. Akceptowane są te prototypy, które test użyteczności przeszły pozytywnie. Pozwala to przede wszystkim zminimalizować koszty związane z tworzeniem modelu biznesowego. Ponadto, by rozwiązanie nie zatrzymało się na poziomie testowania, potrzebne są takie struktury jak think tanki, do tanki oraz design laby" (Olejniczuk-Merta i Nowak, 2015, s. 14).

\subsection{Podtrzymywanie innowacji (Sustaining)}

Jest to etap, na którym innowacje społeczne często stają w obliczu kluczowego napięcia, jakim jest chęć współpracy i pozostanie otwartym a potrzebą ochrony interesów finansowych realizowanego projektu. Przedsięwzięcie, które jest napędzane misją społeczną, ma interes w tym, aby rozpowszechniało się tak szeroko, jak to możliwe i generowało jak największy wpływ społeczny, co często jest sprzeczne z interesami komercyjnymi. Jednym z głównych wyzwań jest więc pozostanie otwartym na współpracę, zapewniając jednocześnie przetrwanie na poziomie finansowym (The Young Foundation, 2012, s. 38). Zaangażowani interesariusze mogą wspomóc redukowanie tego napięcia w podtrzymywaniu innowacji społecznej, dostarczając odpowiednich narzędzi i rozwiązań.

\subsection{Upowszechnianie (Scaling)}

Na etapie upowszechniania innowacji, kluczowym elementem staje się współpraca z partnerami, którzy mają zasoby oraz możliwości, aby wesprzeć ten proces, a więc głównie z administracją publiczną oraz biznesem. Wskazuje się na bardzo dużą rolę administracji publicznej, która poprzez odpowiednie polityki, tworzenie ram formalno-prawnych, ma możliwość systemowego wsparcia innowacji społecznej. Istotne jest to zwłaszcza z punktu wspierania rozwoju przedsiębiorczości społecznej. Przedsiębiorstwo społeczne jest niejako łącznikiem pomiędzy trzecim sektorem a sektorem prywatnym, przez co staje się jedną z istotniejszych instytucjonalnych form budowania powiązań pomiędzy społeczeństwem obywatelskim, a gospodarką rynkową (Hausner i Laurisz, 2008, s. 10).

\subsection{Zmiana systemowa (Systematic change)}

Innowacje społeczne są nieodłącznie powiązane ze zmianą sposobu działania czy konceptualizowania i określania potrzeb społecznych. W tym znaczeniu, zmiana systemowa jest ostatecznym celem innowacji społecznej, nawet jeśli tylko nielicznie innowacje osiągają ten 
etap. Należy podkreślić, że zmiana systemowa nigdy nie jest osiągana przez pojedynczą organizację czy sektor. Zawsze dotyczy ona złożonych interakcji pomiędzy kulturą, zachowaniami konsumentów, praktyką biznesową, ustawodawstwem i polityką. Co więcej, zawsze wiąże się ze zmianą zachowań oraz wymaga od ludzi patrzenia i myślenia w nowy sposób (The Young Foundation, 2012, s. 41).

Bez względu na etap wdrażania innowacji społecznych, wartość i znaczenie kształtowania odpowiednich relacji z interesariuszami i ich zaangażowania wydaje się kluczowe. "Czynnikiem, który zwiększa sukces innowacji społecznych, jest horyzontalne połączenie między interesariuszem (a nie pionowe połączenie między organizacją a interesariuszem). Wspieranie tych połączeń może pomóc w stworzeniu społeczności wirtualnej. Poprzez włączenie interesariuszy do sieci organizacyjnej stają się oni nie tylko bliżsi organizacji, ale także bliżej innych ważnych członków sieci" (Bhattacharya, 2013, s. 148).

\subsection{Proces mapowania i kategoryzowania interesariuszy w innowacjach społecznych}

Proces mapowania interesariuszy, bez względu czy jest realizowany dla firmy, organizacji pozarządowej, czy innowacji społecznej, jest pierwszym i niezbędnym elementem w budowaniu relacji z interesariuszami. Nie jest możliwe właściwe zarządzanie kontaktami z interesariuszami, jeśli nie poznamy grup, podmiotów czy instytucji, które do nich należą. Tym bardziej, że nie wymaga dużych nakładów.

Zadanie to może wykonać osoba indywidualna czy zespół pracujący nad daną innowacją w ramach pracy własnej czy zespołowej burzy mózgów. Można również oprzeć się na bardziej angażujących metodach, jak m.in. burzy mózgów z innymi organizacjami, które uczestniczyły w podobnych działaniach, konsultacjach z zespołem i wymianie wiedzy, opracowaniu „mapy myśli" (mind map), oparciu się o dostępne dane czy statystyki, metodę kuli śnieżnej, gdzie jeden interesariusz identyfikuje kolejnych, wykorzystaniu istniejących spisów organizacji w celu wyłonienia określnych grup, sieci itp. (Durham i in., 2014, s. 37-38).

Efektem mapowania interesariuszy jest stworzenie mapy interesariuszy, najczęściej w formie graficznej. Mapy interesariuszy są uznawane za narzędzie biznesowe pozwalające $w$ formie graficznej zaprezentować wszystkie grupy interesariuszy, zgodnie z przyjętym podziałem na kategorie.

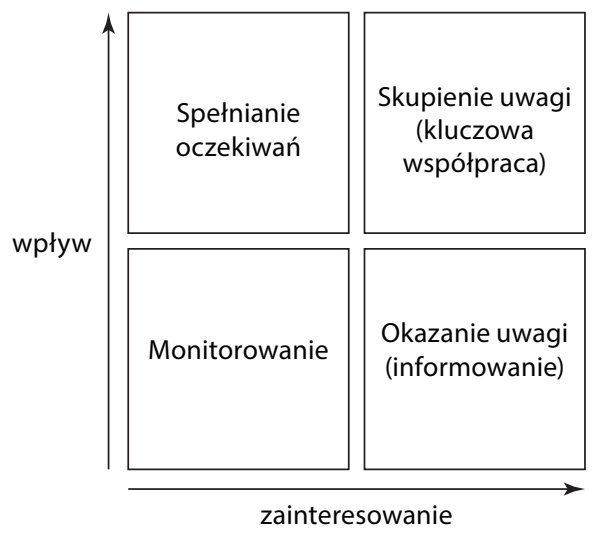

Rysunek 2. Kategoryzowanie interesariuszy

Źródło: opracowanie własne na podstawie: (Bryson, 1995, s. 41). 
Różne podejścia wskazują inne sposoby klasyfikowania interesariuszy, od podziałów prostych, do złożonych. Najbardziej powszechnym jest tworzenie mapy interesariuszy w oparciu o cztery główne kategorie, będące wypadkową zainteresowania i wpływu (Bryson, 1995, s. 41). Dostępne są różne wariacje, jeśli chodzi o stosowane nazwy tych kategorii. Najczęściej określa się te grupy poprzez działania, jakie należy wobec nich podjąć, czyli: monitorowanie, spełnianie oczekiwań, okazanie uwagi (informowanie), skupienie uwagi (kluczowa współpraca), co prezentuje rysunek 2 .

\subsection{Angażowanie interesariuszy w innowacje społeczne}

Problemy i wyzwania, na które odpowiadają innowacje społeczne mają często złożony charakter, często w sposób oczywisty przebiega proces angażowania wielu stron, zainteresowanych jej efektywnym wdrożeniem. Jak już było podkreślane, zaangażowanie interesariuszy pozwala lepiej poznać potrzeby i zrozumieć oczekiwania beneficjentów czy potencjalnych odbiorców danej innowacji społecznej. Pozwala również na uzyskanie dostępu do istotnych zasobów, jak łatwiejsze pozyskanie kapitału finansowego, ludzkiego, wizerunkowego czy wiedzy.

Mapowanie i kategoryzacja interesariuszy jest podstawą w całościowym procesie zarządzania interesariuszami. W przypadku angażowania interesariuszy podkreśla się, że są to wysiłki nakierowane na zrozumienie i włączenie interesariuszy oraz ich obaw w działania oraz w proces podejmowania decyzji (Partridge i in., 2005, s. 6). Interesariusze mogą być angażowani w innowacje społeczne w różnym zakresie co zostało zobrazowane na rysunku 3.

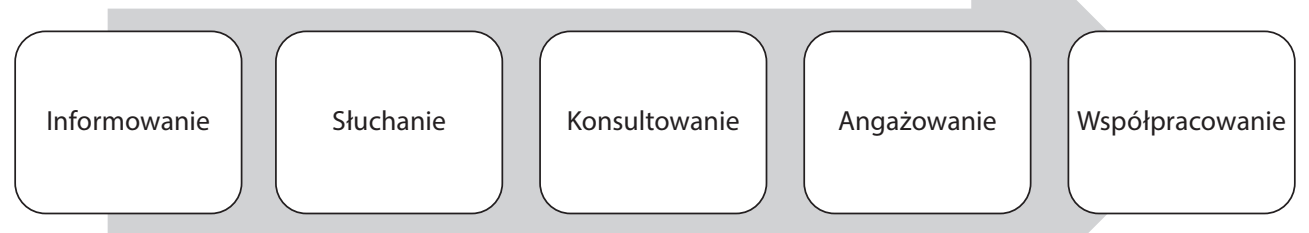

\section{Rysunek 3. Etapy angażowania interesariuszy w innowacje społeczne}

Źródło: opracowanie własne na podstawie: (Cariani, 2017, s. 12).

W ramach podejmowanych działań na każdym z tych etapów, stosuje się różne podejścia dotyczące komunikowania i angażowania interesariuszy (por. rysunek 3):

- Informowanie: Komunikacja jednokierunkowa: organizacja do interesariusza, bez zaproszenia do odpowiedzi;

- Słuchanie: Komunikacja jednokierunkowa: interesariusz do organizacji;

- Konsultowanie: Komunikacja ograniczona dwukierunkowa: organizacja zadaje pytanie, interesariusz udziela odpowiedzi;

- Angażowanie: Zaangażowanie dwukierunkowe lub wielostronne. Nauka wielokierunkowa, jednak interesariusze i organizacja działają niezależnie; 
- Współpracowanie: Zaangażowanie dwukierunkowe lub wielostronne. Wspólna nauka, podejmowanie decyzji i działania (Cariani, 2017, s. 12).

W zależności od poziomu współpracy wykorzystuje się różnorodne narzędzia, od tych przeznaczonych do komunikacji jednostronnej, jak newslettery, informacje prasowe, przez organizowanie spotkań, konferencji, warsztatów, po tworzenie komitetów, rad czy aliansów na rzecz innowacji społecznej.

\section{Konkluzje}

Proces angażowania się interesariuszy w powstawanie innowacji społecznej z jednej strony może wydawać się działaniem oczywistym, a z drugiej istnieją przesłanki, wskazujące na to, że zarówno w ujęciu teoretycznym, jak i praktycznym, nie jest to temat często analizowany, ani tym bardziej wdrażany. Istotne wydaje się kontynuowanie podjętej analizy oraz prowadzenie badań, które przybliżą to zagadnienie od strony empirycznej.

Odpowiednio i rzetelnie przeprowadzony proces identyfikowania, analizy, kategoryzowania oraz angażowania interesariuszy ma wiele korzyści, co zostało wskazane w powyższym opracowaniu. Dodatkowo przekłada się na niwelowanie ryzyk związanych z zarzadzaniem nimi.

Jest on jednak czaso- i kosztotwórczy. Wymaga zaplanowania, poświęcenia czasu i zaangażowania oraz przeznaczenia odpowiedniego budżetu. Należy również mieć na uwadze pewne negatywne skutki, jeśli będzie źle lub niewłaściwe zarządzany. Każdy kontakt z interesariuszami, w tym budowanie komunikacji, zarówno jedno-, jak i dwukierunkowej, włączenie ich w projekt, jak i inne podejmowane w stosunku do nich działania, wiążą się z rozbudzeniem oczekiwań, chęcią zaangażowania, czy możliwość wpływania na innowacje. Aby budowana z interesariuszami relacja była wartościowa, konieczne jest budowanie jej w oparciu o transparentność oraz właściwie dopasowaną komunikację na każdym z etapów współpracy.

\section{Literatura}

Andrejczuk, M., Abec, A. (2014). Dialog i budowanie relacji z interesariuszami - podręcznik dla firm. Warszawa: Forum Odpowiedzialnego Biznesu.

Bhattacharya, C.B. (2013). The Importance of Marketing for Social Innovation, W: T. Osburg, R. Schmidpeter (red.). Social Innovation: Solutions for a Sustainable Future (s. 147-154). Heidelberg, New York, Dordrecht, London: Springer Science \& Business Media.

Bryson, J. (1995). Strategic Planning for Public and Nonprofit Organizations. San Francisco, CA: Jossey-Bass.

Cahill, G. (2010). Primer on social innovation. A compedium of definitions developed by organizations around the world. The Philanthropist, 23(3), 259-272.Cariani, R. (2017). Concept for Stakeholders Engagement, Interreg Central Europe. CERecon - CE119. Deliverable D.T1.1.2. Pobrane z: www.interreg-central.eu/Content.Node/ home.html (dostęp: 30.05.2019).

Chybicka, A. (2017). Outside the box. Jak myśleć i działać kreatywnie. Sopot: Gdańskie Wydawnictwo Psychologiczne.

Durham, E., Baker, H., Smith, M., Moore, E., Morgan, V. (2014). The BiodivERsA Stakeholder Engagement Handbook. Paris: BiodivERsA.

European Commision (2013). Guide to social innovation. Regional and Urban Policy. Pobrane z: https://s3platform. jrc.ec.europa.eu/documents/20182/84453/Guide_to_Social_Innovation.pdf (dostęp: 30.05.2019).

Freeman, R.E. (1984). Strategic Management: A Stakeholder Approach. Boston: Pitman.

Goldenberg, M., Kamoji, W., Orton, L., Williamson, M. (2009). Social Innovation in Canada: An Update. Ottawa: Canadian Policy.

Hausner, J., Laurisz, N. (2008). Czynniki krytyczne tworzenia przedsiębiorstw społecznych. Przedsiębiorstwo społeczne. Konceptualizacja. W: J. Hausner (red.). Przedsiębiorstwa społeczne w Polsce. Teoria i praktyka (s. 9-35). Kraków: Małopolska Szkoła Administracji Publicznej Uniwersytetu Ekonomicznego w Krakowie. 
Lubimow-Burzyńska, J. (2014). Proces tworzenia innowacji społecznych. W: J. Wyrwa (red.). Innowacje społeczne w teorii i praktyce (s. 72-93). Warszawa: Polskie Wydawnictwo Ekonomiczne.

Mencwel, J., Wygnański, J. (2014). Głos Stoczni - Innowacje społeczne. Warszawa: Pracowania badań i innowacji społecznych Stocznia.

Moulaert, F., Nussbaumer J. (2005). Defining the Social Economy and its Governance at the Neighbourhood Level: a methodological reflection. Urban Studies, 42(11), 2071-2088.

Mulgan, G. (2012). Social Innovation Theories: Can Theory Catch Up with Practice?, W: H.W. Franz, J. Hochgerner, J. Howaldt (red.). Challenge Social Innovation (s. 19-42). Berlin, Heidelberg: Springer.

Murray, R., Caulier-Grice, J., Mulgan, G. (2010). The Open Book of Social Innovation. London: Nesta.

Narodowe Centrum Badań i Rozwoju (2019). Program Innowacje społeczne. Pobrane z: www.ncbr.gov.pl/programy/programy-krajowe/innowacje-spoleczne (dostęp: 30.05.2019).

Neumeier, S. (2012). Why do Social Innovations in Rural Development Matter and Should They be Considered More Seriously in Rural Development Research? - Proposal for a Stronger Focus on Social Innovations in Rural Development Research. Sociologia Ruralis, 52(1), 48-69.

Niziński, P. (2014). Innowacje społeczne - od idei do upowszechniania efektów. Podsumowanie konferencji. Warszawa: Akademia Leona Koźmińskiego, Ministerstwo Nauki i Szkolnictwa Wyższego, Instytut Badań Rynku, Konsumpcji i Koniunktur.

Ogburn, W.F. (1969). Kultur und sozialer Wandel. Ausgewählte Schriften. Berlin: Neuwied.

Olejniczuk-Merta, A., Nowak, A. (2015). Wdrażanie innowacji społecznych w Polsce. Podsumowanie konferencji. Warszawa: Akademia Leona Koźmińskiego, Ministerstwo Nauki i Szkolnictwa Wyższego.

Partridge, K., Jackson, Ch., Wheeler, D., Zohar, A. (2005). The Stakeholder Engagement Manual. The Guide to Practitioners' Perspectives on Stakeholder Engagement. Cobourg Ontario: Stakeholder Research Associates Canada Inc.

The Young Foundation (2012). Social Innovation Overview: A deliverable of the project: The theoretical, empirical and policy foundations for building social innovation in Europe (TEPSIE). European Commission - 7th Framework Programme. Brussels: European Commission, DG Research.

Wiktorska-Święcka, A., Moroń, D., Klimowicz, M. (2015). Zarządzanie innowacjami społecznymi. Trendy, perspektywy, wyzwania. Warszawa: Difin.

Wyrwa, J. (2014). Innowacje społeczne w teorii nauk ekonomicznych, W: J. Wyrwa (red.). Innowacje społeczne w teorii i praktyce (s. 41-71). Warszawa: Polskie Wydawnictwo Ekonomiczne.

\section{The role of stakeholders in social innovations}

Summary: In the modern world, the role and importance of social innovations as solutions to existing social or sustainable development challenges is growing. Research suggest that it is not possible to design and implement social innovation effectively without the involvement of significant stakeholder groups. The purpose of this article is to analyse the existing as well as potential future solutions for identifying and engaging stakeholders in social innovation. The work is based on a review of published research and literature. It presents available mapping tools and stakeholder engagement frameworks. The conclusions confirm that cooperation with stakeholders is an important element in developing social innovation, allowing a better understanding of the nature of challenges, the needs of beneficiaries as well as affecting access to important resources.

Keywords: social innovations; innovation; stakeholders; engagement

JEL codes: O35; L3; Z12

\section{Informacje o autorze}

\section{Daria Murawska}

ORCID: 0000-0002-6035-4535

Katedra Socjologii

Instytut Nauk Socjologicznych i Pedagogiki

Szkoła Główna Gospodarstwa Wiejskiego w Warszawie

ul. Nowoursynowska 161, bud. 4, 02-787 Warszawa

e-mail: daria_murawska@sggw.edu.pl 


\section{Prawa autorskie i licencja / Copyright and License}

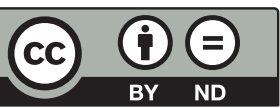

Publikacja na licencji Creative Commons Uznanie autorstwa Użycie niekomercyjne - Bez utworów zależnych 4.0 Międzynarodowe (CC BY-ND 4.0) http://creativecommons.org/licenses/by-nc-nd/4.0/deed/pl

This work is published under the terms of the Creative Commons Attribution - NoDerivetives International (CC BY-ND 4.0) License http://creativecommons.org/licenses/by-nc-nd/4.0

Wydane przez Uniwersytet Ekonomiczny w Krakowie. Małopolska Szkoła Administracji Publicznej

Published by Cracow University of Economics - Krakow, Poland. Małopolska School of Public Administration of the Cracow University of Economics 